\title{
Implementation of Participation Theory in Legal Transmission Determining the Fault of Corruption Criminals
}

\author{
M. Musa \\ Faculty of Law, Universitas Islam Riau (UIR), Indonesia \\ Email:musa@law.uir.ac.id
}

\begin{abstract}
Participation theory in criminal law is a theory used to determine the classification of perpetrators' acts and faults involved in criminal acts. Legal reasoning to determine the actions and faults of participating in corruption is implemented the judge in the process of proof in court. Participation theory is the basis for judges to apply the norms for the inclusion of Article 55 of the Indonesian Criminal Code to the acts of participating in the criminal act of corruption. There are two participation theories used by judges in determining the actions and faults in corruption. The participation theory which broadens the convictions of people is a theory based on the monistic law school used by the judex facti judge to determine the actions and faults of the perpetrators using the method of deductive reasoning. The theory and method used by the judex facti judge results in a decision oriented to formalistic truth. For judex jure judges, in assessing the judex factie decision, they tend to use participation theory which broadens the scope of action, which is a participation theory based on dualistic law school. The method of inductive reasoning is the method used by judex jure judges, and the syllogism in reasoning assumes the norm as the broader major premise of fact as a minor premise. The emphasis of judex jure judges in assessing the act is also put in the state of the perpetrator in committing a crime. The determination of proven actions and faults is assessed in terms of the blasphemy that exists in the physical or mental of the perpetrator. The judex facti judge decision that releases the defendant from criminal liability for his/ her act and fault is assessed and canceled by the judex jure judge based on the mistake in assessing and applying the law to the facts of the case being tried.
\end{abstract}

Keywords-participation theory; judge reasoning; corruption

\section{INTRODUCTION}

Corruption cases, in general, always involve several people who commit the crime. The current applicable corruption law does not specifically regulate participation crime, so the provisions of Article 55 of the Criminal Code are applied to the criminal acts of corruption. In the process of proving a participation criminal act, judge plays an important role in carrying out the legal reasoning to determine the mistakes of each of the participating acts as well as the criminal acts. The determination of the participation act in corruption is the object of the research presented in this paper. Three cases of corruption were investigated related to the collaboration among the government officials as the state finance managers and the private sector as the users of the state finances. The corruption cases were the granting of credit given by Bank Riau-Kepri to PT. SP for financing the take-over of Mall and Shop Houses in Batam, the corruption case in the purchase of fertilizers performed by the Director of the Regional Company (PD) of SPS owned by the Regional Government of Siak Regency from PT. BSL, and the corruption in the procurement of videotron at the Office of the Ministry of Cooperatives and Small and Medium Enterprises (Koperasi dan UKM) in Jakarta. The judge's decision on the act of participating in the cases of corruption indicated a discrepancy in the principle of judgments between the judex facti and judex jure judges in determining the faults of the criminals. The decision differences in the three cases were the scope of the study object studied. The focus of the research problem was on "The application of participation theory of the legal reasoning by the judges to determine the fault of participation and the criminal act of corruption".

In the author's exploration, there were three previous authors who had conducted the research with the objects on the participation in criminal acts. First: the research on the application of participation school in Indonesian criminal justice conducted by [6]. Second: the research on the problem of legal reasoning patterns in the study of the decision on the cases of customary lands investigated by [11], [12]. Third: the research report on the responsibility of the participation perpetrator in a crime which was carried out by [24]. The three studies have a fundamental difference from the author's research. The optic of the author's research was related to the application of participation theory in judge reasoning in deciding the act of participating in the crime of corruption. 


\section{RESEARCH METHOD}

There were two methods of research approach according to Rony Hanitijo Soemitro; normative juridical and empirical juridical [13]. The approach method used in this study was empirical juridical approach with normative legal research specification. The type of the data collected was in the form of primary data sourced from the interviews with the ad hoc judges of corruption cases and the results of Focus Group Discussion. The secondary data were taken from three documents of the decisions of the Pekanbaru and Jakarta Corruption Criminal Courts. The analysis of the research data used normative-qualitative method. The legal materials for analyzing the data consisted of primary legal materials, such as legislations, secondary legal materials including the textbooks that contain legal theories and reasoning, journals, websites, and other online media. The research data was presented in descriptive-analytical form.

\section{RESULT AND DISCUSSION}

\section{A. Implication of participation theory application to the perpetrator's fault participating in corruption crime}

Normatively, the norm provisions of Article 55 paragraph 1 of the Criminal Code regulate the types of perpetrators (pleger) in the making group (dader) [9], [10], to distinguish the types of perpetrators in the helper class (mede plichtigheid) in criminal acts regulated in Article 56 of the Criminal Code. The determination of the difference in role classification as the doer (pleger) in the group of makers (dader) is important to determine the faults or criminal liability of each perpetrator. The determination of the acts and fault of criminal acts is known in two participation theories; the expansion theory on the ability to sentence the person and the expansion theory on the ability to sentence the action. The participation theory applied by the judges is essentially the process of finding the truth at the stage of proof and a step towards the end of determining the fault of the perpetrator to be subject to conviction or punishment. In the corruption case of providing investment credit at Bank Riau-Kepri, the Managing Director and Marketing Director were sentenced to imprisonment along with the Branch Manager of Bank Riau-Kepri. The three bank officials were found guilty of providing credit facilities to PT. SP which was found not to meet the eligibility standard to get credit and get a project tender. Guy Benvenste defines such corruption as discretionary corruption; the corruption committed because of the freedom in determining policy [29]. The decision was free from all claims (onslag) from the judex facti because the judges believed the defendant AW, Director of PT. SP, who was tried in the Case Number 39 / Pid.Sus / 2013 / PN.PBR was not proven to have participated in committing a criminal act of corruption. The decision of the Judex Pacti judges was no different from the decision of the corruption case for the purchase of fertilizer carried out by AA as the Director of PD. SPS belongs to the Siak Regency
Government. The actions were also proven, but the actions were also participated by SB, the Director of PT. BSL who made a sale and purchase agreement against AA and decided as onslag. The Judex Facti Judges who adjudicated these two cases had similar legal considerations in determining the actions and faults of the perpetrator that the defendant's actions were a violation of law included in private jurisdiction. According to [11], [12], in civil law disputes, personal dimension (individual parties) is more prominent than that in public law disputes. From the results of the interview, the onslag decision imposed on the act of participating of the private as the contract recipient was proven not to implement the terms of the agreement, and it is indeed a mistake that is included in the provisions of private law. In contrast to the verdicts to the perpetrators of participating in the state financial management, it was proven to fulfill all the elements of the fault of corruption because the defendant misused the state finance management.

The view of the judge saw that the participating act did not necessarily be blamed for being convicted. The judex fatie judge's decision illustrated the freedom to determine the criteria for faults of participating in a crime. The consideration of the judex facti judges can be understood when it follows the opinion of [9], [10], who states that those who participate do not necessarily need to be involved as suspect. The judges' decisions appeared to emphasize the state financial managers who are considered eligible to be found guilty of participating in a criminal act, while the private sector was proven to be involved but could not be blamed based on the criminal law. When considering the view of [5], the crime of participating in committing a crime includes two things; the presence of conscious cooperation and joint implementation [5]. The application of this view was otherwise seen to be applied in the judex pacti verdict in the case of vidieotron. The perpetrators who participated from the government as the manager of state finances and the private party were found guilty and sentenced. Basically, the judex facti judges, in applying the law, were the concretization of the application of the provision of law. The provisions of the norms of participation in the provisions of the Criminal Code are principally adhering to the view of criminal acts from a monistic school, which unites acts and faults as criminal acts. Therefore, the formulation of the school also serves to expand criminal responsibility (Utrech, 1965: 9). According to [2], the monistic school in its teaching views participation as the basis for broadening the ability of people (strafausdehnungsgrund), while the dualistic school sees "participation to broaden the possibility to sentence actions (tatbestand ausdehnungsgrund)" [2]. The judge who applies the provisions of the law is a reflection of monistic school, in carrying out the examination to hold firmly to the principle of strict legality. The principle of legality contains the elements of scripta, stricta and certa, as the rule that cannot be violated by a judge when applying the law.

The judex pacti judge's decision at the Supreme Court's appeal was canceled. The judex jure judges stated in the verdict that the defendant was found guilty of participating in a 
criminal act. The Judex Jure Judges assessed that the elements of the fault of participation from the defendant of private party were proven because the defendant's awareness of the nonfulfillment of the conditions for obtaining credit approval and the inability to obtain the project was a manifestation of evil and despicable intentions. Likewise, in the case of purchasing fertilizer, it is considered that the private sector's act utilized an oral agreement made between them. The typology of such corruption mode according to Syed Husein Alatas is called transactive corruption, which is a type of reciprocal agreement corruption (Situmorang: 2014: 333). From the results of the research by Emerson Yuntho and Illian Deta Arta, it showed the other reasons is that it is necessary for judges to be careful to decide corruption acts because corruption is an extraordinary crime. The perpetrators are intellectuals and have an important position, so they were easy to divert/ hide the property that comes from the result of corruption [18]. Therefore, in overcoming corruption, it is necessary to have proper corruption eradication legal politics, namely synchronizing vertical and horizontal legal political policies [23]. The errors in legal considerations were found because they only focused on the procedural technical matters of the agreement used as principle facts in reasoning and resulting in bias decision. According to [11], [12], heretical legal reasoning may occur in the context of converce accident which is the justification of arguments because they only focus on certain traits/ characters considered inherent.

On the contrary, from the judex pacti decision of the videotron case that convicted the defendant HS, the Director of PT. IM, judex judges judged that the decision was wrong. Judex Jure's judicial legal reasoning in the legal consideration of the fact that the defendant's mental state did not fulfill the element of the indicted article. HS. who does not graduate elementary school, worked as an office boy positioned as a director in a neatly made way. HS was proven to be deceived and did not have the intellectual and managerial ability to hold the director position conditioned by his employer. The typology of such corruption is called defensive corruption; other parties achieve the goal by deceiving others involved in the corruption process [28].. The judex jure judgea stated in the verdict that the defendant was not guilty of committing the acts and was sentenced in onslag. The judex jure judge's decision can be understood as a thought that assessed participation as an extension on the possibility to sentence that depart from dualism. The principle of participation theory to determine the fault of the act of participation started from the propriety of the subjective conditions contained in the perpetrators. The element of fault in a broad sense as written by Henry Donald Lbn. Toruan is the inner relationship of the maker with his actions [30]. The side of the ability to do, the knowledge in understanding the work and intellectual conditions, and the nature of self-indulgence in the perpetrator are the determinants according to the judges to determine the presence of fault in participating acts.

The strict elements of legality principle were no longer questioned the Judex Jure in seeking material truth. The judges had carried out a textual interpretation of the fault of the participant written in the law. Resolving legal issues juridically in its essence, according to Nur Iftitah Isnantiana, means that applying the rules of positive law to the problem (case) could only be done contextually and interpreted the rule of law to find the legal rules contained therei [19].. Barda Nawawi Arief states that, in normative criminal law in principle, the aspect of "norm" is an external aspect or an outward aspect that appears and materializes in the formulation of legislation, and the aspect of "value" is an inner or mental aspect behind the norm[2]. The development of the judex jure judge's decision is in line with the view of modern criminal law which had inspired an understanding of the principle of legality. In modern criminal law, Douglas N. Husak and Craig A. Callender, as quoted by [7], Knowledge, and the Equal Performance", Thesis: A Study of The Deeper Significance of the Principle of Legality ", that Fidelity to law cannot be construed as fidelity to statutory law, but must be understood as fidelity to the principle of justice that underlie statutory law [7].

\section{B. The method of legal reasoning in determining the fault of participating act as well as the criminal act}

Legal reasoning from judges is an act of thinking of judges which has a meaning as a process of thinking of carrying out practical law that comes from certain legal problems or cases [11], [12], [25], [26], [27]. According to van Vursen, the reasoning is known as the reasonings of induction, deduction and abduction methods. Deduction and induction reasoning begin with observation" [3]. Thinking in induction way is thinking from concrete things drawn on a general conclusion called abstraction. Concretion is also a deduction process because the things formulated are generally applied to specific circumstances. The three types of reasoning are the activities of the logical thinking process using logic methods in the area of practical reasoning [1]. Regarding thinking process, the method of legal reasoning in the settlement of cases is strongly influenced by the individual judges' paradigms of the case situation and the legal knowledge of the judge. Paradigm as a model in the theory of science or a framework of thinking, according to Thomas Khun, is a basic assumption and general theoretical assumptions which is a source of laws, methods, and application in science [14].

The paradigm possessed by the judge will affect the subjectivity of juridical thinking in analyzing and determining the resolution of cases. Kenneth $J$. Vandevelde makes the criteria epistemologically into seven steps in legal reasoning, such as: identifying the applicable sources of law, analyzing the sources of law, synthesizing the applicable rules of law into a coherent structure, researching the available facts, and applying the structure of rules to the facts, formulation, and solution [16]. Legal reasoning from judex facti judges in determining fault and criminal offenses in all three cases, epistemologically showed a decision that followed the steps of analyzing legal positivism with a doctrinal-deductive reasoning method. Legal positivism does not consider the validity of positive law in terms of its material but that of its formality. Reference [8] 
states that to comply with the law in legal positivism is not it is not due to the contents which are considered good or fair, but it has been determined by the legitimate authorities [8]. Thus, the ontological problem of the act in the new criminal law is called an unlawful act solely when the act is contrary to the law. The onslag decision that was declared by the judges to be a part of the private sector's involvement in the case above was a reflection of the application of the doctrinal-deductive reasoning method. This reasoning method model initially confirmed the norm as a major premise to be a means of achieving legal certainty. Shidarta considers that the cores of legal certainty is predictability, which is the ability to perceive "an individual ought to behave in a certain way" [11], [12], [25], [26], [27].

The judges who adjudicated the three cases were based on written law in analyzing the cases, and such things become a truth that positive legal norms are assumed to have been made by considering the philosophical principles, values and principles of truth and justice [11], [12]. Furthermore, the law enforcement by adhering to written laws is explained by Arthur Dyevre: there are many things in a typical judicial opinion on constitutional matters that legal positivists will regard as nonlegal and thus non-constitutional, so long as the judicial opinion is compatible with their positivist credo [17].

From the explanation, the decision made by judex pacti is a decision that reflects the application of deductive reasoning. In the deductive syllogism, norm as a major premise is assumed that it covers facts and is broader than the fact of the case being tried as a minor premise. This concept, according to [8], explains that major premise is positioned as the concept of orthodoxy, axiomatically considered able to cover and even anticipate all legal issues [8]. The consequence of this method of reasoning is that law enforcers are required to be able to give precise meaning [11], [12], so the choice of legal reasoning methods for judges gives meaning in the application of participation theory. According to [6], the choice of participation school is important to get the meaning of the offenses of participation and inclusion [6]. Judge's reasoning for the determination of fault from a criminal act is a reasoning process for legal conclusions. The reasoning based on normative boundary determines the "ought" and not to the reality of "is". The deductive reasoning used by the judex facti judges in adjudicating the case was the application of legality principles which, according to [8]., is a strict concept that adheres to legal procedural principles [8]. It must be admitted that decision making is not just an issue of induction, deduction, or analogical reasonings, but the demand for every decision to be reasonable and logical may also always be a necessity that cannot be negotiated [32].

The principles of the procedure, according to [4], is a procedure that seeks the truth by looking at the truth of the base as the ideal axiomatical truth (self-evident) with the essence of truth that does not need to be questioned [4]. Judges in this case only assessed schematically and mathematically between legal facts and norms. It can be assumptively stated that when the evidence is sufficient and the judge is convinced of the truth, the judge must impose a criminal sentence [31]. Louis Kattsoff states that "Logic is divided into two main branches; deductive and inductive. Inductive logic is related to drawing conclusions from real individual cases into general conclusions, while deductive logic helps in drawing conclusions from general things into individual cases [21].

The method of inductive reasoning is seen to be used in the judex jure judge's decision when adjudicating the two defendants of onslag decision for the case of credit granting and the sale and purchase of fertilizers. The judex facti verdict sentenced HS, Director of PT. IM, in the case of videotron procurement. This legal reasoning made by judex jure, in Fitzgerald's terms, is called functional interpretation because the judges did not bind themselves fully to the sentence and the words of the regulation (litera legis). The reasoning tries to understand the true purpose of a regulation by using various other sources which are considered to provide more satisfying clarity [20]. Hence, the interpretation of judex jure's decision regarding criminal liability still did not come out of litera legis, and the fault was only charged to the personal director and did not reach the corporation. According to [22], the imposition of corporate errors was identified in the guilt of the defendant as a high managerial agent of the corporation. Consequently, criminal penalties are imposed on both administrators and corporations [22].

\section{CONCLUSION}

The judex facti judges in determining the fault of participation tent to apply participation theory which broadened the sentencing of person. The decision adhered to the strict legality principle so that the decisions made only resulted in formal justice. The judex factie judge's decision in determining the fault emphasized more on the expansion theory of the sentencing of act based on the consideration that the decision is more in search of the substance of the facts in an effort to find material truth. The judex factie judges in reasoning sylogism made the conclusions using the method of deduction reasoning with the predictability of the norm covering all facts. The judex jure, in concluding the fault, used induction reasoning method by initially looking for the facts found to be able to apply the legal provisions.

\section{REFERENCES}

[1] Abdullah. Pertimbangan Hukum Putusan Pengadilan. Surabaya: Bina Ilmu, 2008.

[2] Arief, Barda Nawawi. KONGGRES ILMU HUKUM INDONESIA, Refleksi dan Rekonstruksi llmu Hukun Indonesia, Kerjasama ASHI (Asosiasi Sosiologi Hukum Indonesia) dan Bagian Hukum dan Masyarakat FH UNDIP, Semarang., 19-20 October 2012

[3] Blackburn, Simon. Kamus Filsafat Buku Acuan Paling Terpercaya di Dunia, Yogyakarta: Penerbit Pustaka Pelajar, 2013. 
[4] Dimyati, Khuzaifah. Pemikiran Hukum Konstruksi Epistemologis Berbasis Budaya Hukum Indonesia. Yogyakarta: Genta Publishing, 2014.

[5] Farid Andi, Zainal Abidin \& Andi Hamzah. Bentuk-bentuk Khusus Penwujudan Delik dan Hukum Penetensier. Jakarta: Sumber Ilmu Jaya, 2002.

[6] Fitriasih, Surastini. Penerapan Ajaran Penyertaan dalan Peradilan Pidana Indonesia (Studi Kasus Tindak Pidana Korupsi, Pelatggaran HAM Berat dan Terorisme). Universitas Indonesia, 2006

[7] Morawetz , Th.(Ed.). Criminal Law. Burlington, USA: Ashgate Publishing Comp. Burlington, 2000.

[8] Putro Dwi,Widodo. Kritik Terhadap Paradigma Positivisme Hukum. Yogyakarta: Genta Publishing., 2011.

[9] Saleh, Roeslan. Kitab Undang-Undang Hukum Pidana Dengan Penjelasan. Jakarta: Aksara Baru, 1989.

[10] --------------Tentang Delik Penyertaan, Pekanbaru: UIR Press, 1997.

[11] Shidarta. Karakteristik Penalaran Hukum Dalam Konteks Keindonesiaan. Bandung: CV.Utomo, 2006.

[12] --------. Hukum Penalaran dan Penalaran Hukum Buku 1 Akar Filosofis. Yogyakarta: Genta Publishing, 2013.

[13] Soemitro, Rony Hanitijo,. Metodologi Penelitian Hukum dan Jurimetri. Jakarta: Ghalia Indonesia, 1990.

[14] Surajiyo. Filsafat dan Perkembangan di Indonesia. Jakarta: PT. Bumi aksara, 2008.

[15] Utrecht. Hukum Pidana II. Bandung: Penerbitan Universitas, 1965.

[16] Vandevelde, Kenneth J. Thinking Like A Lawyer: An Introduction to Legal Reasoning.Colarado: Westview Press, 1996.

[17] Dyevre, Arthur \& András Jakab. Foreword: Understanding Constitutional Reasoning. German Law Journal, Vol.14. No.08. pp.984-1016, 2013.

[18] Emerson Yuntho, Emerson dan Deta, Illian, dkk. (2014). Hasil Penelitian Penerapan Unsur Merugikan Keuangan Negara Dalam Tindak Pidana Korupsi, Jakarta: Indonesia Corruption Watch.

[19] Iftitah Isnantiana, Nur Iftitah. (2017). Legal Reasoning Hakim Dalam Pengambilan Putusan Perkara di Pengadilan. Jurnal Pemikiran Islam Islamadina, Volume XVIII, No. 2, Juni 2017. pp,42-56

[20] Muda, Iskandar. (2016). Penafsiran Hukum Yang Membentuk Keadilan Legal Dalam Penyelesaian Sengketa Berbankan Syariah. Jurnal Yudisial Vol. 9 No. 1 April 2016. pp. 37 - 50

[21] Nurjaya, I Nyoman. (1983). Penalaran Hakim Dalam Menciptakan Hukum (Judge- Made-Law); Suatu Kegiatan Berpikir Ilmiah, Jurnal Hukum dan Pembangunan, Juli 1983. pp. 297-306.

[22] Prahassacitta, Vidya. (2016). Menyoal Pertanggungjawaban Pidana PT.IM2 Dalam Perkara Tindak Pidana Korupsi Kajian Putusan Nomor 787 K/PID.SUS/2014. Jurnal Yudisial Vol. 9 No. 1 April 2016. pp. 93 - 112

[23] Risnain, Muh. (2014). Kesinambungan Politik Hukum Pemberantasan Korupsi (Sustainability of Corruption Eradication Legal Policy). Jurnal Rechtsvinding Media Pembinaan Hukum Nasional, Volume 3 Nomor 3 Desember 2014. pp,311-327

[24] Sambulele Susanty, A. (2013). Tanggung Jawab Pelaku Penyertaan Dalam Tindak Pidana (Pasal 55 dan 56 KUHP). Jurnal Lex Crimen, Vol. II/No. 7, pp. 84-92.
[25] Shidarta. (2011). Membidik Penalaran Hakim Dibalik Skor Kosong-Kosong Dalam Kasus Prita Mulasari, Jurnal Yudisial, Vol-IV/No-03. pp. 251-261.

[26] Shidarta. (2010). Peragaan Pola Penalaran Hukum Dalam Kajian Putusan Kasus Tanah Adat. Jurnal Yudisial, Vol-III/No-03. pp, 207-219.

[27] Shidarta. (2013). Konsep 'malum in se' dan 'malum prohibitum' Dalam Filosofi Pemberantasan Korupsi. Jurnal Masalah-Masalah Hukum, Jilid 42 No.1. pp. 88-96.

[28] Situmorang, Mosgan. (2014). Harmonisasi Hukum Nasional di Bidang Korupsi Dengan United Nations Convention Against Corruption. Jurnal Rechtsvinding Media Pembinaan Hukum Nasional, Volume 3 Nomor 3 Desember 2014. pp,329-346

[29] Suharyo. (2014). Optimalisasi Pemberantasan Korupsi Dalam Era Desentralisasi di Indonesia. Jurnal Rechtsvinding Media Pembinaan Hukum Nasional, Volume 3 Nomor 3 December 2014. pp,365-380.

[30] Toruan, Henry Donald Lbn. (2014). Pertanggungjawaban Pidana Korupsi Korporasi. Jurnal Rechtsvinding Media Pembinaan Hukum Nasional, Volume 3 Nomor 3 Desember 2014. pp, 397-416.

[31] Widodo, Fajar.J. (2011). Pranata Hukum, Volume 6 No.2 Juli 2011. pp. 133-142.

[32] Weruin, Urbanus Ura. (2017). Logika, Penalaran, dan Argumentasi Hukum. Jurnal Konstitusi, Volume 14, Nomor 2 , Juni 2017. pp,375-395. 